\title{
PELAKSANAAN WAKAF WASIAT DAN AKIBAT HUKUMNYA KETIKA HARTA WARISAN DIPAILITKAN
}

\author{
Margaretha ${ }^{1}$ \\ ${ }^{1}$ Fakultas Hukum Universitas Udayana, E-mail: margaretha8311@gmail.com
}

\begin{tabular}{l}
\hline Info Artikel \\
\hline Masuk : 2 Februari 2020 \\
Diterima : 28 April 2020 \\
Terbit : 30 April 2020 \\
Keywords : \\
Keywords: Waqf; Wasiat; \\
Heritage Property; Insolvent
\end{tabular}

Kata kunci:

Wakaf; Wasiat; Harta Warisan; Pailit

Corresponding Author:

Margaretha, E-mail:

margaretha8311@gmail.com

DOI :

10.24843/AC.2020.v05.i01.p05

\begin{abstract}
The Law Number 41 in 2004 regarding Waqf (Waqf Law) and The Law Number 37 in 2004 regarding Bankruptcy and Suspension of Debt Payment Obligations do not regulate about the object of waqf wasiat when the property of inheritance have been declared bankrupt by the court. This way can be effected legal problem, because in Article 40 of the Waqf Law stipulates that the object of waqf are prohibited from being confiscated. Whilst, in Article 1 paragraph (1) of The Law Number 37 in 2004 determines that when a bankruptcy occurs, all debtor assets will be confiscated. This research purpose to examine the execution of wasiat waqf in Indonesia and the consequence of wasiat waqf when the inheritor's inheritance is declared insolvent. The research method used normative legal by using the constitution and conceptual approach. The resource of legal material is used consists of primary and secondary legal materials. The technique of collecting legal materials using snowball techniques and the analytical method used is descriptive analysis. The results of this research that: firstly, the implementation of wasiat waqf will be carried out by the procedure of representarion in Indonesia. Second, when the inheritor's inheritance is declared insolvent, the inheritance can be determined as insolvent boedel to pay the inheritor's debts. If the inheritance is exhausted, then the wasiat waqf will be canceled, but if there is still remaining, then $1 / 3$ of the remaining inheritance can be taken to carry out the inheritor's wasiat.
\end{abstract}

\footnotetext{
Abstrak

Undang-Undang Nomor 41 Tahun 2004 Tentang Wakaf (UU Wakaf) dan Undang-Undang Nomr 37 Tahun 2004 Tentang Kepailitan dan Penundaan Kewajiban Pembayaran Utang (UUK-PKPU) tidak mengatur megenai objek wakaf wasiat dari harta warisan ketika dinyatakan pailit oleh Pengadilan. Hal ini tentu saja menimbulkan problematik hukum, dikarenakan dalam Pasal 40 UU Wakaf menentukan bahwa harta yang diwakafkan dilarang untuk dilakukan penyitaan. Sedangkan dalam Pasal 1 ayat (1) UUK-PKPU menentukan bahwa ketika terjadi pailit, maka seluruh harta kekayaan debitor akan dilakukan penyitaan. Penelitian ini bertujuan untuk meneliti mengenai pelaksanaan wakaf melalui wasiat di Indonesia dan akibat hukum wakaf
} 
wasiat ketika harta warisan pewaris dinyatakan pailit. Metode penelitian yang digunakan adalah penelitian hukum normatif dengan pendekatan Undang-Undang, dan pendekatan konseptual. Sumber bahan hukum yang digunakan terdiri dari bahan hukum primer dan sekunder. Tehnik pengumpulan bahan hukum menggunakan tehnik bola salju dan metode analisis yang digunakan adalah analisis deskriptif. Hasil penelitian ini menyimpulkan bahwa: pelaksanaan wakaf wasiat dilakukan dengan tata cara perwakafan di Indonesia dan akibat hukum wakaf wasiat ketika harta warisan pailit, maka harta warisan dapat ditetapkan sebagai boedel pailit untuk membayar hutanghutang pewaris. Jika harta warisan tersebut habis maka wakaf wasiatnya menjadi batal, namun jika masih terdapat sisa, maka 1/3 dari sisa harta warisan tersebut dapat diambil untuk melaksanakan wakaf wasiat pewaris.

\section{Pendahuluan}

Wakaf adalah suatu perangkat ekonomi yang dapat dimanfaatkan untuk aktifitas umat Islam dan mengentaskan masalah kemiskinan. Pemberdayaan wakaf di Indonesia jika dibandingkan negara-negara Islam lainnya, seperti Mesir, Arab Saudi, Turki, Malaysia dll. dapat dikatakan belumlah maksimal. Negara-negara tersebut telah mampu mengembangkan wakaf sebagai suatu lembaga di bidang sosial ekonomi bagi umat Islam untuk membantu bermacam kegiatan ibadah dan mampu menyelesaikan permasalahan kemiskinan. ${ }^{1}$

Wakaf adalah salah satu cara ibadah harta atau al-'ibadah al-maliyah, yang bersifat sosial selain zakat, infaq, dan sedekah. Wakaf dilaksanakan dengan memisahkan harta milik orang-perorangan, organisasi atau badan hukum dan melembagakan untuk keperluan ibadah atau keperluan lainnya sesuai syariat hukum Islam, dengan harapan untuk mendapatkan pahala yang akan terus mengalir kepada wakif walaupun telah meninggal. Wakaf berarti membekukan harta untuk memungut manfaatnya tanpa menjadikan harta wakaf tersebut habis seketika, pemanfaatannya dikhususkan untuk hal-hal yang diijinkan sesuai syara' dan bertujuan untuk menperoleh keridhaan dari Allah SWT. Secara hukum, dengan mewakafkan harta maka wakif telah kehilangan hak kepemilikannya dan tidak memiliki kewenangan lagi untuk menggunakannya secara pribadi, baik untuk menjual, menghibahkan, atau mewariskan harta tersebut. Pada prinsipnya harta yang telah mewakafkan menjadi milik umat dan manfaatnya harus dapat dirasakan oleh umat. ${ }^{2}$

Pelakanaan wakaf sebagai al-'ibadah al-maliyah tidak ada secara khusus pengaturannya di dalam Al- Qur'an. Wakaf merupakan bentuk itjihad para ulama, yaitu metode pemutusan hukum syariat yang mengerahkan segenap pikiran dan energi dengan sungguh-sungguh, yang dilakukan oleh para ulama dengan melakukan penafsiran atas perintah-perintah Allah S.W.T. yang terdapat dalam Al-Qur'an dengan

1 Sulistiani, S. L. (2017). Analisis implementasi wakaf wasiat polis asuransi syariah di lembaga wakaf al-Azhar Jakarta. Ijtihad: Jurnal Wacana Hukum Islam dan Kemanusiaan, 17(2), 285-299., h.286.

2 Abdullah, J., \& Qodin, N. (2016). Penyelesaian Sengketa Wakaf Dalam Hukum Positif. ZISWAF: Jurnal Zakat dan Wakaf, 1(1), 1-18., h.39. 
berpedoman pada hadist Raullullah SAW. Aturan mengenai wakaf yang terdapat pada Al Qur'an tidak setegas seperti aturan zakat, sedekah dan infaq, namun aturan wakaf tumbuh dan berkembang dalam kajian hukum dan budaya masyarakat Islam. ${ }^{3}$

Wakaf pertama kali diatur dalam Undang-undang Nomor 5 Tahun 1960 Tentang Peraturan Dasar Pokok-Pokok Agraria (UUPA) yaitu pada Pasal 49 mengenai pemberian tanah yang dikuasai secara langsung oleh Negara, melalui hak pakai untuk keperluan ibadah dan keperluan sosial dan keagamaan. Dalam perkembangannya, wakaf kemudian diatur pada Buku III Kompilasi Hukum Islam (KHI), UndangUndang Nomor 41 Tahun 2004 Tentang Wakaf (UU Wakaf), Peraturan Pemerintah Nomor 42 Tahun 2006 Tentang Pelaksanaan UU Wakaf, yang kemudian diubah menjadi Peraturan Pemerintah Nomor 25 Tahun 2018 Tentang Perubahan atas Peraturan Pemerintah Nomor 42 Tahun 2006 Tentang Pelaksanaan UU Wakaf (PP Wakaf). ${ }^{4}$ Aturan tersebut tidak hanya berisi pengaturan mengenai harta benda wakaf tetapi juga pengaturan mengenai tata cara perwakafan dan pengelolaannya serta pengaturan wakaf melalui wasiat.

Wakaf wasiat adalah wakaf yang pelaksanaanya baru dapat dilakukan ketika orang yang berwasiat telah meninggal dunia, dalam hal ini penerima wasiat berkedudukan sebagai kuasa dari orang yang berwasiat. Kata wasiat berasal dari bahasa Arab yaitu wasa yang mengandung arti membuat janji. ${ }^{5}$ Wasiat menurut istilah fiqih dapat dipersamakan dengan berderma dalam bentuk harta setelah seseorang meninggal atau amanat seorang yang meninggal untuk melakukan suatu perbuatan. ${ }^{6}$ Wasiat juga dapat didefiniskan dengan amanat, baik berupa harta benda ataupun lainnya. Sedangkan berdasarkan hukum Islam, wasiat berarti amanat khusus dari seseorang yang akan meninggal dan dapat dilaksanakan setelah orang tersebut meninggal dunia. Sehingga wasiat bermakna pengumuman atas hajat seseorang tentang sesuatu yang akan diperbuatnya atas harta bendanyanya setelah ia meninggal dunia. ${ }^{7}$ Dalam KHI wasiat bermakna pemberian atas harta benda yang dimiliki seseorang kepada orang lainnya atau lembaga lain yang akan berlaku setelah orang tersebut meninggal dunia. ${ }^{8}$

UU Wakaf mengatur mengenai wakaf dengan wasiat dalam beberapa pasal, yaitu:

1. Pasal 24, mengatur mengenai tata cara pelaksanaan wakaf.

2. Pasal 25, mengatur mengenai syarat dan besaran harta wakaf yang pelaksanaannya melalui wasiat.

3. Pasal 26, mengatur mengenai pelaksanaan wakaf wasiat yang dilaksanakan setelah pewasiat meninggal dunia yang dilakukan oleh penerima wasiat.

Berdasarkan ketentuan dalam UU Wakaf tersebut diatas, maka dimungkinkan untuk melakukan wakaf melalui wasiat, namun yang menjadi sorotan adalah mengenai objek

\footnotetext{
${ }^{3}$ Hilmi,H.(2012). Dinamika pengelolaan wakaf uang: studi sosio-legal perilakupengelolaan wakaf uang pasca pemberlakuan UU No. 41 tahun 2004 tentang wakaf. Ijtihad: Jurnal Wacana Hukum Islam dan Kemanusiaan, 12(2), 123-143.,h.124.

${ }^{4}$ Hermawan, W. (2014). Politik hukum wakaf d Indonesia. Jurnal Pendidikan Agama Islam Ta'lim, 12(2). h.152.

${ }^{5}$ Muhamad,N.H. N. (2017). Wasiat Sebagai Instrumen Perancangan Harta Islam: Prosedur Dan Pelaksanaan. (Bequest as an Instrument for Islamic Wealth Planning: Procedure and Application). Jurnal Hadhari: An International Journal, 9(1), 17-32., h.19.

6 Al-Fauzan, S.(2006). Fiqih sehari-hari. Jakarta: Gema Insani h.545.

7 Uwaidah, S. K. M., \& Kamil, S. (1998). Fiqih wanita Jakarta: Pustaka Al-Kautsar. h.491-492.

${ }^{8}$ Lihat Pasal 171 huruf f Kompilasi Hukum Islam
} 
wakaf, yaitu ketika harta warisan dinyatakan pailit oleh putusan pengadilan, sedangkan dari harta warisan tersebut terdapat wasiat untuk mewakafkan sebagian hartanya. Undang-Undang Nomor 37 Tahun 2004 Tentang Kepailitan dan Penundaan Kewajiban Pembayaran Utang (UUK-PKPU) tidak mengatur mengenai kepailitan harta warisan yang didalamnya terdapat wakaf wasiat, UUK-PKPU hanya mengatur kepailitan harta warisan dapat terjadi ketika dua atau lebih kreditor mengajukan permohonan kepailitan untuk harta peninggalan tersebut, sebagaimana diatur dalam Pasal 207 UUK-PKPU. Menurut Pasal 1 ayat (1) UUK-PKPU, kepailitan merupakan sita umum atas semua kekayaan debitor pailit. Berdasarkan ketentuan tersebut, ketika harta warisan dinyatakan pailit, maka seluruh harta warisan tersebut akan dilakukan penyitaan. Namun menurut Pasal 40 UU Wakaf menentukan bahwa harta yang telah diwakafkan dilarang untuk dilakukan penyitaan. Tentu saja hal ini dapat menimbulkan problematik hukum dikarenakan UU Wakaf dan UUK-PKPU belum mengatur mengenai hal ini, sehingga terjadi kekosongan hukum terhadap penyelesaiannya.

State of the art diambil dari penelusuran beberapa contoh penelitian terdahulu yang digunakan sebagai panduan dan acuan dalam melakukan penelitian ini, yaitu berupa jurnal-jurnal antara lain :

1. Jurnal berjudul "Tinjauan Hukum Islam Terhadap Pembatalan Tanah Wakaf Pada Putusan Nomor 1562/PDT.G/2013/PA.JU" oleh Ria Kurniawati, Nunung Rodliyah, dan Selvia Oktaviana dari Universitas Lampung pada tahun 2019 yang meneliti mengenai alasan-alasan dari kasus pembatalan akta wakaf yang dikaji dari Hukum Islam dan UU Wakaf dan pertimbangan Hakim dalam memutuskan perkara tersebut serta akibat hukum yang timbul dari pembatalan tanah wakaf. Kesimpulan yang didapatkan bahwa alasan-alasan pembatalan akta ikrar wakaf adalah Surat Ikrar Wakaf dan Surat Pengesahan Nazhir Nomor W5/430/26 tidak sesuai dengan UU Wakaf dan Kompilasi Hukum Islam (KHI). Pertimbangan Hakim dalam Putusan Nomor 1562/Pdt.G/2013/PA.JU adalah tidak memenuhi UU Wakaf dan Peraturan Pemerintah Nomor 42 Tahun 2006 tentang Pelaksanaan UU Wakaf, karena Tergugat bukan pemilik sah dari tanah tersebut. Akibat hukum yang timbul adalah Akta Ikrar Wakaf dianggap tidak pernah ada.

2. Jurnal berjudul "Akibat Kepailitan Terhadap Harta Peninggalan Dikaitkan dengan Undang-Undang Nomor 37 Tahun 2004 Tentang Kepailitan dan Penundaan Kewajiban Pembayaran Hutang" oleh Harry V. C. Kapero dari Universitas Sam Ratulangi pada tahun 2018 yang meneliti mengenai kedudukan hukum ahli waris debitor terhadap putusan pailit dan akibat kepailitan terhadapa harta peninggalan dikaitkan dengan Undang-Undang Nomor 37 Tahun 2004 Tentang Kepailitan dan Penundaan Kewajiban Pembayaran Hutang. Kesimpulan yang didapatkan bahwa Kedudukan hukum ahli waris debitor terhadap putusan pailit belum diatur secara terperinci dalam ketentuan tersebut, dan pernyataan pailit mengakibatkan harta kekayaan orang yang meninggal dunia demi hukum dipisahkan dari harta kekayaan pribadi para ahli warisnya.

\section{Metode Penelitian}

Metode yang digunakan pada penelitian ini adalah penlitian hukum normatif, dimana terdapat kekosongan norma sehubungan dengan pelaksanaan wakaf wasiat ketika harta warisan dipailitkan, dimana tidak adanya pengaturan yang tegas baik pada UU 
Wakaf maupun pada UUK-PKPU mengenai objek harta warisan tersebut ketika terjadi kepailitan oleh Putusan Pengadilan. Pendekatan yang digunakan dalam penelitian ini adalah pendekatan perundang-undangan dan pendekatan konseptual, dengan sumber bahan hukum yang digunakan terdiri dari bahan hukum primer dan bahan hukum sekunder. Tehnik pengumpulan bahan hukumnya menggunakan tehnik bola salju, serta dianalisis dengan menggunakan analisis deskriptif.

\section{Hasil Dan Pembahasan}

\subsection{Tata Cara Pelaksanaan Wakaf Wasiat}

Menurut istilah syariat dalam Islam, wakaf adalah bentuk donasi yang perwujudannya dilaksanakan dengan jalan membekukan status kepemilikan asalnya (tahbisul ashli), lalu pemanfaatannya dipergunakan untuk kepentingan umum. Tujuan dari tahbisul ashli yaitu dengan membekukan benda yang diwakafkan itu agar tidak dapat dilakukan upaya untuk mewariskan, menjual, menghibahkan, menggadaikan, menyewakan dan sejenisnya. Dan pelaksanaannya dilakukan sesuai dengan keinginan orang yang berwakaf tanpa adanya kompensasi atas perbuatan tersebut. ${ }^{9}$ Unsur-unsur wakaf yang termuat dalam UU wakaf, yaitu pada Pasal 6 terdiri dari :

1. Wakif, yaitu orang atau badan hukum yang melepaskan hartanya untuk dijadikan sebagai harta wakaf.

2. Nazhir, adalah orang atau badan hukum yang melaksanakan dan mengelola pemanfataan harta wakaf yang diterima berdasarkan peruntukannya agar dapat berkembang.

3. Harta Wakaf, adalah asset yang diserahkan oleh wakif untuk diwakafkan. Harta benda tersebut harus mempunyai nilai ekonomi menurut syariah, memiliki daya tahan lama dan dapat dimanfaatkan untuk waktu yang lama.

4. Ikrar Wakaf, adalah Pernyataan atau niatan wakif untuk melakukan wakaf atas harta miliknya yang dilakukan melalui tulisan atau secara lisan kepada Nazhir.

5. Pemanfaatan harta benda wakaf, yaitu dipergunakan sebagai fasilitas dan penunjang aktifitas ibadah, pendidikan dan kesehatan. Dapat juga diperuntukkan untuk pertolongan kepada orang-orang miskin, yatim piatu dan bea siswa bagi masyarakat tidak mampu. Serta bisa dipergunakan juga untuk perkembangan ekonomi umat muslim dan kesejahtraan umum lainnnya yang syaratnya harus sesuai dengan syari'ah Islam dan peraturan perundangundangn.

6. Jangka waktu wakaf, bahwa pemanfaatan harta wakaf boleh dengan jangka waktu tertentu atau dapat pula untuk selama-lamanya.

Benda-benda yang dapat diwakafkan menurut KHI Pasal 1 ayat (4) adalah benda yang tidak hanya sekali pakai namun juga memiliki nilai menurut ajaran Islam, benda tersebut dapat berupa benda bergerak ataupun benda tidak bergerak. Sedangkan menurut UU Wakaf Pasal 1 ayat (5), bahwa benda wakaf adalah benda yang awet untuk waktu lama dan bermanfaat untuk waktu yang panjang serta bernilai ekonomis. ${ }^{10}$ Untuk benda-benda yang dapat diwakafkan sebagaimana diatur dalam ketentuan Pasal 215 ayat 4 KHI jo Pasal 16 UU Wakaf, dapat berupa :

\footnotetext{
9 Al Arif, M. N. R., \& Rianto, N. (2010). Pemberdayaan masyarakat berbasis wakaf uang. Jurnal AsySyir'ah, Fakulti Syariah UIN Sunan Kalijaga Yogyakarta, 44(2), 813-828., h.3.

10Irawati, N.(2017). Wakaf Benda Bergerak Dalam UU No.41 Tahun 2004 Dalam Tinjauan Fiqh Mazhab Syafii. Istidal: Jurnal Studi Hukum Islam, 4(2), 149-162., h.151.
} 
1. Benda tidak bergerak yaitu meliputi :

a. Hak atas tanah, dapat berupa Hak Milik, Hak Guna Bangunan, Hak Guna Usaha, Hak Pakai di atas tanah negara atau tanah bekas Hak Milik Adat.

b. Bangunan atau bagian bangunan yang berdiri di atas tanah.

c. Tanaman dan benda lain yang berkaitan dengan tanah.

d. Hak milik atas satuan rumah susun

2. Benda bergerak yaitu benda yang tidak habis apabila dipergunakan, meliputi : uang, logam mulia, surat berharga, kendaraan, hak atas kekayaan intelektual, atau hak sewa dan lain sebagainya.

UU Wakaf mengatur mengenai pelaksanaan wakaf wasiat. Sebutan untuk wakaf wasiat bersumber dari kata wasiat. Wakaf wasiat merupakan perencanaan wakaf melalui wasiat yang dilakukan secara legal terhadap sebagian dari asset yang dimiliki oleh wakif yang kemudian diberikan sebagai wakaf ketika si wakif masih hidup, namun pelaksanaanya baru dapat terlaksana ketika si wakif meninggal dunia. ${ }^{11}$ Wakaf dan wasiat dalam Islam termasuk sedekah yang pelaksanaannya bukan suatu kewajiban tetapi kedudukannya sangat mulia dan mendapat jaminan pahala. Wakaf dan wasiat memiliki pengertian dan aturan masing-masing. Wakaf merupakan bentuk sedekah barang yang hanya mengambil manfaat atas benda yang diwakafkan, barangnya tetap ada, yang berpindah hanya kepemilikannya saja. Sedangkan wasiat merupakan sedekah dengan harta yang pelaksanaanya setelah orang yang berwasiat meninggal. Sehingga wakaf wasiat merupakan bentuk ibadah yang pelaksanaanya mulai berlaku ketika wakif) meninggal dunia. Perbedaan penting antara wakaf dan wasiat, diantaranya:

1. Pada wakaf, harta benda wakaf ditahan yang diserahkan hanya manfaatnya saja, sedangkan wasiat diserahkan sepenuhnya kepemilikannya baik bendanya maupun manfaatnya setelah terjadinya kematian pewasiat.

2. Status wakaf adalah pasti, menurut mayoritas ulama tidak diperbolehkan menarik kembali wakaf, sedangkan wasiat tidaklah pasti. Diperbolehkan bagi orang yang berwasiat untuk menarik semua yang dia wasiatkan atau sebagiannya.

3. Pada wakaf, benda yang diwakafkan keluar dari kepemilikan seseorang, penerima wakaf (nazhir) hanya menerima untuk mengelola dan mengembangkan harta tersebut, nazhir tidak memiliki hak kepemilikan dan pemanfaatannya dikhususkan kepada yang diwakafkan. Sedangkan benda yang diwasiatkan akan menjadi milik sepenuhnya orang yang menerima wasiat, sehingga penerima wasiat berhak sepenuhnya atas benda wasiat tersebut.

4. Kepemilikan dan manfaat wakaf sudah terjadi ketika pemberi wakaf masih hidup atau sudah meninggal dunia, sementara wasiat ditetapkan hukum kepemilikannya setelah pewasiat meninggal, sehingga serah terima yang dilakukan sebelum kematian dianggap tidak berkekuatan hukum.12

5. Harta yang akan diwakafkan tidak ada batasan maksimal, sedangkan harta yang akan diwasiatkan memiliki batasan yaitu tidak boleh lebih dari sepertiga bagian harta pewasiat kecuali atas izin ahli waris.

6. Wakaf boleh diberikan kepada ahli waris, sementara wasiat jika ingin memberikan kepada ahli waris harus berdasarkan perstujuan ahli waris yang lainnya terlebih

11 Sulistiani, S. L. Op.Cit., h.290.

12 Nuzha,N. (2015). Wasiat dan Hutang dalam Warisan. Jurnal Al-Qadau: Peradilan dan Hukum Keluarga Islam, 2(2), 207-228., h.212. 
dahulu.

7. Berkenaan dengan akad wakaf atau wasiat. Akad wakaf akan terlaksana seketika itu juga saat seseorang menyatakan kehendak wakafnya, seperti mengatakan: "aku mewakafkan tanahku" atau "aku mewakafkan kebunku", maka hal tersebut menjadi barang wakaf saat itu juga. Sementara wasiat, baru akan terlaksana setelah meninggalnya orang yang memberi wasiat.

Mengenai tata cara wakaf wasiat, menurut Pasal 26 ayat (3) UU Wakaf menentukan bahwa wakaf dengan wasiat dilaksanakan sesuai dengan tata cara perwakafan, sehingga wakaf wasiat tata cara pelaksanannya sama seperti wakaf pada umumnya, hanya implementasinya baru dapat dilaksanakan ketika si pewasiat meninggal dunia.

Wakaf juga dianggap sebagai perbuatan yang dilakukan oleh seseorang yang menimbulkan hak dan kewajiban terhadap pihak lain atau dapat dikatakan sebagai sebagai perbuatan hukum sepihak. Perbuatan hukum sepihak tersebut terjadi, begitu adanya keinginan yang dinyatakan oleh wakif untuk mewakafkan sebagian hartanya, maka begitu wakif menyatakan keinginannya, perbuatan wakafnya telah terjadi. Namun pelaksanaan wakaf menurut undang-undang baru terjadi begitu diucapkan ikrar wakafnya oleh siwakif/kuasa wakif kepada Nadzir didepan Pejabat Pembuat akta Ikrar Wakaf (PPAIW) dan harus disaksikan oleh dua saksi. Ikrar Wakaf tersebut harus diucapkan secara lisan dan/atau dalam bentuk tulisan secara jelas dan tegas, dan kemudian harus dituangkan dalam Akta Ikrar Wakaf (AIW) oleh PPAIW. Apabila untuk menyatakan ikrar wakaf, wakif tidak bisa datang di hadapan PPAIW, maka pelaksanaan ikrar wakaf tersebut dapat digantikan oleh kuasa wakif yang ditunjuk berdasarkan surat kuasa yang diperkuat dengan kesaksian dua saksi.

Akta Ikrar Wakaf memiliki kedudukan yang sangat krusial, dengan adanya Akta Ikrar Wakaf, maka dapat menjamin kepastian hukum, serta dapat memberikan perlindungan, memberikan jaminan atas kelangsungan dan eksistensi perbuatan wakaf, selain itu Akta Ikrar Wakaf dapat dimanfaatkan ketika terjadi persoalan sengketa yang menyangkut harta benda wakaf. ${ }^{13}$ Konflik dalam wakaf biasanya terjadi karena status dan kedudukan wakaf tidak jelas, antara si wakif, nazhir, keluarga wakif atau antara jemaah setempat dengan nazhir-nya ketika si wakif meninggal dunia, serta terkadang ada penolakan atau tidak diakuinya harta benda yang menjadi benda wakaf oleh sebagian ahli warisnya. Karena itu dibuatnya Akta Ikrar Wakaf sangat penting agar perbuatan hukumnya yang dilakukan oleh wakif menjadi terjamin kepastain hukumnya. Akta Ikrar Wakaf juga dapat dipergunakan untuk mengajukan perubahan status atas benda wakaf, yaitu dapat menjadi dasar untuk melakukan perubahan status atas tanah yang sebelumnya merupakan hak milik wakif menjadi benda wakaf melalui sertifikat wakaf dengan mengajukan perubahan tersebut ke Badan Pertanahan Nasional (BPN) atau Badan Wakaf Indonesia (BWI) setelah semua syarat administrasinya terpenuhi. ${ }^{14}$

Pembuatan Akta Ikrar Wakaf dilakukan oleh Pejabat Pembuat Akta Ikrar Wakaf (PPAIW). Menurut UU Wakaf, PPAIW adalah pejabat yang memiliki kewenangan

\footnotetext{
13Husein, A.A.(2012). Pelaksanaan undang-undang wakaf Nomor 41 Tahun 2004 di Kecamatan Gebang Kabupaten Langkat (Doctoral dissertation, Pascasarjana UIN Sumatera Utara)., h.9.

14 Samsidar, S. (2017). Urgensi, Alat Bukti Akta Ikrar Wakaf Dalam Penyelesaian Sengketa Perwakafan. Jurnal SUPREMASI, 11(2), 142.,h.142
} 
untuk membuat Akta Ikrar Wakaf. PPAIW itu sendiri ditetapkan oleh Menteri Agama. ${ }^{15}$ Menurut ketentuan Pasal 37 PP Wakaf, bahwa lembaga atau pihak yang berhak menjadi PPAIW yaitu

(1) Kepala KUA, yaitu untuk membuat Akta Ikrar Wakaf untuk benda wakaf berupa benda tidak bergerak seperti tanah.

(2) Kepala KUA atau Pejabat lain yang ditunjuk oleh Menteri Agama, yaitu untuk membuat Akta Ikrar Wakaf untuk benda wakaf berupa benda bergerak selain uang.

(3) Pejabat Lembaga Keuangan Syariah yang ditunjuk oleh Menteri Agama, yaitu dalam pembuatan AIW untuk wakaf benda bergerak berupa uang.

(4) Notaris yang telah memenuhi persyaratan sebagai pejabat Pembuat Akta Ikrar Wakaf yang ditetapkan oleh Menteri Agama.

Menurut ketentuan tersebut, maka lembaga dan pihak-pihak yang dapat ditunjuk sebagai PPAIW, selain Kepala KUA dan Pejabat Lembaga Keuangan Syariah adalah Notaris. Notaris dapat ditunjuk sebagai PPAIW untuk harta benda wakaf selain berbentuk uang, berdasarkan penetapan Menteri Agama Republik Indonesia. Mengenai tata cara Perwakafan, KHI mengatur dalam Pasal 223 dan Pasal 224. Kemudian tata cara perwakafan pengaturannya juga ada dalam PP No. 42 Tahun 2006 Pasal 38-44. Adapaun tata cara wakaf, yaitu:

1. Untuk melaksanakan ikrar wakaf, maka wakif atau kuasanya menyatakan kehendaknya dengan ikrar wakaf di hadapan PPAIW yang kemudian dibuatkan Akta Ikrar Wakaf dimana isi dan bentuk aktanya tersebut ditentukan oleh Menteri Agama.

2. Akta ikrar wakaf dinyatakan sah apabila dibuat dengan dihadiri dan disaksikan oleh sekurang-kurangnya dua orang saksi.

3. Sebelum Pembuatan Akta tersebut, maka wakif atau kuasanya terlebih dahulu harus melampirkan sertifikat atau tanda bukti atas kepemlkann untuk benda yang akan diwakafkan tersebut kepada PPAIW. Jika benda wakaf adalah benda tidak bergerak, maka harus ada pernyataan tertulis bahwa tanahnya tersebut bebas dari sengketa, tidak dalam keadaan berperkara, tidak dalm status sitaan dan tidak sedang menjadi jaminan. Pernyataan tertulis tersebut harus diketahui oleh Kepala Desa atau Lurah dan diperkuat oleh Camat setempat.

4. Harta benda wakaf harus didaftarkan selambat-lambatnya tujuh hari kerja sejak penandatanganan akta ikrar wakaf oleh PPAIW atas nama Nazhir kepada Instansi yang berwenang.

5. Untuk mendaftarkan benda wakaf berupa tanah, maka pendaftaran sertifikat tanah wakaf dimohonkan oleh PPAIW kepada Badan Pertanahan Nasional (BPN) atas dasar Akta Ikrar Wakaf. Untuk tanah berstatus hak milik yang diwakafkan hanya sebagiannya saja, maka sertifikat hak miliknya harus dilakukan pemecahan terlebih dahulu. Untuk tanah yang berstatus hak guna bangunan, hak guna usaha atau hak pakai di atas tanah negara, maka harus disetujui oleh BPN untuk dilakukan pelepasan hak. Untuk bangunan seperti masjid, mushalla, makam, yang didirikan di atas tanah Negara, maka bisa langsung didaftarkan menjadi tanah wakaf.

6. Untuk wakaf tanah yang belum tercatat, tidak mempunyai akta ikrar wakaf dan belum bersertikat tanah wakaf, maka harus dapat diajukan permohonan

${ }^{15}$ Lihat Pasal 1 ayat (6) Undang-Undang No.41 Tahun 2004 Tentang Wakaf 
pengesahan (itsbat) wakaf ke Pengadilan Agama, agar memiliki kepastian hukum. Terkait dasar hukum kewenangan Pengadilan Agama dalam menangani permohonan itsbat wakaf, maka dapat dilakukan melalui konstruksi hukum, dengan menganalogikan Pasal 7 ayat (2) KHI mengenai permohonan itsbat nikah terhadap perkawinan yang belum memiliki Akta Nikah, sehingga untuk wakaf yang belum memiliki akta ikrar wakaf dapat juga dimintakan permohonan itsbat di Pengadilan Agama, dengan syarat adanya kesaksian pihak yang mengetahui perbuatan wakaf tersebut. ${ }^{16}$

7. Untuk mendaftarkan benda wakaf bergerak selain uang, maka PPAIW atas dasar Akta Ikrar Wakaf mendaftarkannya kepada Badan Wakaf Indonesia (BWI). Untuk daerah yang belum ada lembaga BWI, maka dapat didaftarkan di Kantor Departemen Agama setempat.

8. Untuk mendaftarkan benda wakaf berupa uang, maka pendaftarannya ditujuakn kepada Menteri Agama selambat-lambatnya tujuh hari kerja sejak penerbitan Sertifikat Wakaf Uang. Pendataran tersebut diajukan oleh Pejabat Lembaga Keuangan Syariah penerima Wakaf Uang (LKS-PWU) atas nama Nazhir dan kemudian ditembuskan ke BWI untuk diadministrasikan.17

Mengenai penyelesaian ketika terjadi sengketa, maka dapat diselesaikan dengan mekanisme musyawarah mufakat, mediasi dan arbitrase. Jika langkah tersebut telah dilakukan dan gagal, maka UU Wakaf Pasal 62 menetukan bahwa untuk menyelesaikan sengketa perwakafan, maka upaya yang dilakukan adalah melalui pengadilan agama yang merupakan langkah terakhir.

Pada pembahasan ini menggunakan Teori Cita Hukum, menurut Gustav Radbruch, bahwa cita hukum ada tiga, yaitu keadilan, kemanfaatan dan kepastian hukum. Teori cita hukum ini dimaksudkan untuk menekankan pada kepastian aturan, terkait keharusan dibuatnya akta ikrar wakaf pada pelaksanaan wakaf wasiat sehingga dapat memberikan perlindungan dan jaminan atas kelangsungan serta eksistensi perbuatan wakaf. Konsep keadilan hukum mengandung arti, bahwa hukum harus menjamin apa yang menjadi hak dari setiap orang. Sedangkan kemanfaatan berkaitan dengan nilai kegunaan hukum dalam rangka memenuhi kebutuhan hukum masyarakat.

\subsection{Akibat Hukum Wakaf Wasiat Ketika Harta Warisan Pewaris Dinyatakan pailit.}

Pada kasus wafatnya seseorang dalam keadaan tidak melakukan pembayaran hutangnya, atau harta warisannya tidak mencukupi untuk melunasi hutangnya, maka harta kekayaan seorang yang wafat tersebut dapat dinyatakan pailit, apabila diajukan oleh dua atau lebih kreditornya. ${ }^{18}$ Kepailitan merupakan cara untuk menanggulangi debitor yang sedang mengalami permasalahan dalam membayar hutangnya dikarenakan kesulitan keuangan. Pengadilan Niaga menyatakan pailit karena ketidakmampuan debitur dalam melakukan pembayaran hutangnya, sehingga harta kekayaan yang dipunyai oleh debitor dapat dipergunakan untuk membayar hutangnya dengan membagikannya kepada para kreditor sesuai dengan peraturan perundang-undangan yang berlaku. Pailitnya seorang debitor ditetapkan oleh

16 Isna Wahyudi, M.Alimuddin,Rahmat Arijaya. (2017). Hitam Putih Sengketa Wakaf. Majalah Peradilan Agama. Edisi 11 April 2017.h.21

17 Lihat Pasal 43 PP No. 42 Tahun 2006 tentang Pelaksanaan Undang-Undang Nomor 41 Tahun 2004 tentang Wakaf

18 Lihat Pasal 207 Undang-Undang Nomor 37 Tahun 2004 Tentang Kepailitan dan Penundaan Kewajiban Pembayaran Hutang 
Pengadilan Niaga, jika debitor tersebut terbukti mempunyai kreditor dua atau lebih dan tidak mampu melunasi paling sedikitnya satu hutang yang telah jatuh tempo dan bisa dilakukan penagihan. ${ }^{19}$

Menurut UUK-PKPU, Kepailitan merupakan sita umum atas semua kekayaan Debitor Pailit yang pengurusan dan pemberesannya dilakukan oleh Kurator di bawah pengawasan Hakim Pengawas. Kepailitan dapat terjadi jika debitur mempunyai lebih dari satu kreditor dan tidak mampu melunasi sekurang-kurangnya 1 hutang yang sudah memasuki batas akhir pembayaran dan utang tersebut dapat ditagih. Penetapan atas pailitnya seseorang berdasarkan keputusan pengadilan, yang dapat dimohonkan sendiri oleh debitor atau kreditornya atau bisa juga mengajukan kepada kejaksaan demi kepentingan umum. ${ }^{20}$

Menurut Pasal 21 UUK-PKPU, kepailitan mencakup segenap harta kekayaan yang dimiliki oleh debitor ketika dinyatakan pailit, termasuk segala sesuatu yang mungkin akan didapatkannya sepanjang kapailitannya tersebut. Akibat hukum dari putusan pailit, maka hak debitor menjadi hilang sejak ditetapkannya putusan pailit untuk mengendalikan dan mengelola kekayaannya yang termasuk dalam boedel pailit. ${ }^{21} \mathrm{Hal}$ ini berarti, bahwa debitor tidak bisa lagi mengurus dan menguasai harta tersebut walaupun statusnya tetap masih memilliki kekayaan itu. Harta tersebut akan beralih untuk diurus dan dikuasai oleh hakim pengawas dan kurator yang ditetapkan oleh pengadilan niaga, atau Balai Harta Peninggalan (BHP) jika kreditur atau debitur tidak mengusulkan untuk diangkatnya kurator lain kepada pengadilan. ${ }^{22}$ Tujuan diaturnya mengenai kepailitan dan penundaan pembayaran hutang ini adalah $:^{23}$

1. Agar ketika dinyatakan pailit para kreditur tidak secara bersamaan memperebutkan harta debitor dan menagih untuk pelunasan hutang debitor;

2. Untuk mencegah dijualnya barang jaminan yang dipegang oleh kreditur pemgang jaminan tanpa mempertimbangkan keperluan debitur atau para kreditur lainnya;

3. Dan mencegah kreditur atau debitur itu sendiri dari kemungkinan berbuat curang.

Pasal 210 UUK-PKPU menentukan, bahwa seseorang yang sudah meninggal bisa dimintakan permohonan pernyataan pailit terhadap harta kekayaannya dan dimohonkan selambat-lambatnya 90 (Sembilan puluh) hari sejak debitur meninggal. Terhadap kepailitan harta peninggalan, selanjutnya pada Pasal 209 menentukan bahwa pailitnya seseorang yang telah meninggal tidak mengakibatkan adanya percampuran harta yang dimiliki oleh orang yang meninggal dunia tersbut dengan kekayaan pribadi para ahli warisnya, kekayaan pewaris tersebut tetap terpisah dari

\footnotetext{
${ }^{19}$ Pradana,Y.,Susilowati,E.,\& Saptono,H. (2016). Kedudukan Ahli Waris Penanggung Perseorangan pada Perseroan Terbatas yang Dipailitkan secara Bersama-sama. Diponegoro Law Journal, 5(3), 1-19., h.3.

${ }^{20}$ Lihat Pasal 2 ayat (1) dan (2) Undang-Undang Nomor 37 Tahun 2004 Tentang Kepailitan Dan Penundaan Kewajiban Pembayaran Utang

21Sastrawidjaja,M.S.(2006).Hukum Kepailitan dan Penundaan Kewajiban Pembayaran Utang.Bandung. Alumni.h.108

22 Ali, M. C., Mashudi, H., \& Samsuddin, H. A. (1995). Kepailitan dan PenundaanPembayaran. Mandar Maju, Bandung. h.102

${ }^{23}$ Asikin,(2013). Hukum kepailitan dan penundaan kewajiban pembayaran utang di Indonesia. Bandung: Pustaka Reka Cipta. hal. 29
} 
harta pribadi para ahli warisnya. ${ }^{24}$ Ketentuan tersebut sesuai dengan apa yang diatur dalam Pasal 175 ayat (2) KHI, dimana ahli waris tidak bertanggungjawab atas hutang atau kewajiban dari pewaris, kewajiban ahli waris hanya membayarkan hutang pewaris sebatas jumlah atau nilai harta peninggalannya. Sehingga ahli waris tidak berkewajiban untuk membayarkan hutang pewaris dari harta pribadi ahli waris, kecuali atas keikhlasan ahli waris untuk membayar hutang pewaris. Pada proses pewarisan berdasarkan hukum adat dan hukum Islam, harta peninggalan yang dapat diwariskan pada dasarnya hanya sisa dari harta peninggalan tersebut setelah hutanghutang pewaris dibayarkan. Ini bertolak belakang dengan ketentuan yang ada dalam KUHP (Burgerlijk Wetboek). Menurut BW pada proses pewarisan, yang beralih tidak hanya harta warisan saja tetapi juga meliputi utang-utang pewaris. ${ }^{25}$

Adanya putusan pernyataan pailit tidak serta merta mengkibatkan debitur menjadi tidak cakap. Debitor menjadi tidak cakap hanya dalam mengadakan perbuataperbuatan hukum yang berkaitan dengan pengelolaan harta yang dimilikinya. Perbuatan hukum melalui wasiat merupakan perbuatan yang berkaitan dengan harta kekayaan, dimana peralihan hartanya terjadi setelah pewasiat meninggal dan saat itu tanda-tanda pewasiat akan dipailitkan belum ditemukan, sehingga ketika berwasiat, status pewasiat masih dianggap cakap dan mampu melakukan perbuatan hukum. ${ }^{26}$ Namun bagaimana jika wasiat tersebut adalah untuk mewakafkan hartanya, sedangkan Pasal 3 UU Wakaf menentukan bahwa wakaf yang telah diucapkan tidak dapat dilakukan pembatalan, dan wakaf dengan wasiat menurut Pasal 26 ayat (3) UU Wakaf dilaksanakan sesuai dengan tata cara perwakafan.

Menurut Pasal 217 ayat (3) jo Pasal 225 ayat (1) KHI, bahwa benda yang diwakafkan adalah benda milik yang tidak dalam status pembebanan, ikatan, sitaan dan sengketa serta tidak dapat diubah pemanfaatannya selain yang dimaksudkan dalam Akta ikrar wakaf. Pasal 40 UU Wakaf juga menentukan bahwa benda yang sudah diwakafkan terlarang untuk menjadi barang jaminan, terlarang untuk disita, dihibahkan, dijual, diwariskan, ditukar atau dialihkan dalam bentuk pengalihan hak lainny, kecuali pemanfaatnnya bertentangan dan tidak cocok lagi dengan apa yang dimaksudkan dalam Akta Ikrar Wakf atau karena adanya kepentingan umum. ${ }^{27}$

Dinyatakan pailitnya pewaris berarti ada sekurang-kurangnya satu utang yang telah memasuki batas waktu pembayaran namun belum dilunasi dan dapat ditagih. Hutang merupakan hak manusia sedangkan wakaf adalah hak Allah yang merupakan sedekah yang dikeluarkan karena Allah, sehingga tidak boleh diambil kembali. Dalam Permasalahan ini, para ulama memiliki pandangan yang berbeda mengenai mana yang harus lebih dahulu ditunaikan.

1. Pendapat yang pertama, menurut madzhab Hambali, wakaf mulai terhitung sejak

24 Nadriana,L.(2018). Perlindungan Hukum Terhadap Harta Ahli Waris Dari Pewaris Penjamin Akta Personal Gurantee Di Perusahaan Pailit. Jurnal Bina Mulia Hukum, 2(1), 93-105., h.100.

${ }^{25}$ Kapero,H. $\quad$ V. (2018). Akibat Kepailitan Terhadap Harta Peninggalan Dikaitkan Dengan Undangundang Nomor 37 Tahun 2004 Tentang Kepailitan Dan Penundaan Pembayaran Utang. LEX ET SOCIETATIS, 6(2).,h.128

${ }^{26}$ Yusuf Zainal Abidin. (2018). Wasiat Oleh Debitur Pailit dalam

http:/ / www.bhpjakarta.info/index.php?option=com_content\&view=article\&id=317\&Itemid=159. (Diakses 12 Januari 2019).

${ }^{27}$ Lihat Pasal 225 ayat (2) Kompilasi Hukum Islam jo Pasal 41 ayat (1) Undang-Undang No.41 Tahun 2004 Tentang Wakaf 
diucapkan oleh wakif dan tidak mungkin dibatalkan. Namun wakaf hanya dapat dilaksanakan pada 1/3 hartanya atau kurang dari itu. Dalam hal ini madzhab Hambali menggangapnya sebagai wasiat disatu sisi dan sebagai wakaf disisi yang lain.28 Sehingga Harta si pewaris dilakukan pembagian berdasarkan nisbah (persentase) untuk pembayaran hutang-hutang dan pelaksanaan wakaf tersebut, dengan masing-masing mendapat jatah bagian seperti pada kejadian orang yang megalami kebangkrutan, atau pailit. ${ }^{29}$

2. Pendapat kedua menurut madzhab Hanafi dan Maliki, yang dipilih Syaikhul Islam Ibnu Taimiyyah dan inilah pendapat yang lebih kuat mengatakan, bahwa wakaf dalam kondisi seperti itu tidak berlaku dan tidak boleh dilaksanakan. Sebab membayar hutang hukumnya wajib, sedangkan wakaf adalah amal perbuatan sunnah. Dan kita tidak boleh mempersempit sesuatu yang wajib untuk sesuatu yang sunnah. Kecuali jika wakaf telah dilaksanakan, baru terjadi hutang, maka wakaf tersebut harus tetap dilaksanakan. ${ }^{30}$

3. Pendapat madzhab Syafi'i, yaitu diutamakan hak Allah dari pada hak manusia. ${ }^{31}$ Sehingga wakaf harus tetap dilaksanakan dengan diambil dari bagian harta yang dinyatakan pailit. Karena wakaf adalah hak Allah sedangkan hutang adalah hak manusia.

Wakaf wasiat adalah wakaf yang dilakukan melalui wasiat, sehingga wakafnya diperlakukan seperti halnya wasiat. Pelaksanaan wakaf harus memerhatikan beberapa prinsip, yaitu, pertama, harta peninggalan tersebut harus dpisahkan bagiannya untuk pengurusan mayat (jenazah), seperti biaya mengkafani dan biaya permakaman terlebih dahulu. Kedua, setelah biaya permakaman dikeluarkan, harus dilunasi utangutang jenazah terlebih dahulu. Dan ketiga, dikeluarkan wasiat dari jenazah tidak lebih dari sepertiga harta yang tersisa, kemudian baru dibagi warisnya kepada yang berhak. ${ }^{32}$ Sehingga jumlah harta wakaf bisa berkurang jika ternyata harus digunakan untuk membayar utang pewasiat dan pengurusan jenazah.

Terkait dengan hutang, maka pelaksanaan wakaf melalui wasiat harus memenuhi syarat-syarat. Menurut Al Kabisi, ada dua syarat bagi wakif untuk melakukan wakaf, yaitu, 33

1. Wakif tidak terikat dengan hutang

Menurut sebagian mahzab Syafii, wakaf orang yang berhutang hukumnya tidak sah dan dapat dimintakan permohonan permbatalan atas perbuatan wakaf tersebut, sampai wakif telah bebas dari hutang-hutangnya. Hal ini dikarenakan wakafnya orang yang memiliki hutang dapat membuat sulit wakif dalam melunasi hutangnya tersebut. Kemudian menurut mahzab Maliki, wakaf orang yang berhutang tersebut juga hukumnya tidak sah, namun maksud tidak sah atau batal disini adalah karena tidaklah sempurna, dalam hal ini wakafnya tetap sah, namun

28 Bin Shalih al-Utsaimin, S. M. (2008). Panduan wakaf dan Wasiat menurut Al-Qur'an dan As-Sunnah.terj. Hudzaifah, A. Jakarta: Pustaka Imam Asy-Syafi'i. h.88-90

${ }^{29}$ Nuzha, N. ,Loc.Cit.

30 Bin Shalih al-Utsaimin, S. M. Op.Cit. h.90

${ }^{31}$ Nuzha, N. Op.Cit. h.173

32 Lihat,Pasal,17 ayat (1) Kompilasi Hukum Islam jo Pasal 25 Undang-undang No.41 Tahun 2004 Tentang Wakaf.

33 Usman, N. (2016). Subjek-subjek Wakaf: Kajian Fiqh Mengenai Wakif Dan Nazhir. Cakrawala: Jurnal Studi Islam, 11(2), 145-166., h.151. 
tidak perlu dilakukan. Dan menurut Al Kabisi, bahwa orang yang memiliki hutang sepantasnya tidak melakukan wakaf terhadap harta bendanya, baik saat ia dalam keadaan sehat atau sakit sekalipun, bahkan sebelum berada dalam status pengampuan.

2. Wakif tidak dalam kondisi sakit parah

Menurut Al Kabisi, berdasarkan kesepakatan ulama bahwa perbuatan wakif ketika menderita sakit dapat dipersamakan sebagai wasiat sehingga persyaratan dan aturan yang berlaku adalah hukum wasiat. Dan mengenai hukum wakaf, harus dilihat dulu, apakah wakif masih mempunyai utang atau tidak. Jika wakif masih mempunyai utang dan hartanya hanya mencukupi untuk membayar utang, maka wakafnya mengalami kebatalan dan berganti menjadi keharusan membayar utang. Namun jika setelah dilakukan pembayaran utangnya masih terdapat sisa atau utangnya tidak membuat habis seluruh hartanya, maka wakafnya dapat dilakukan dari sisa harta yang dimiliki setelah dibayar lunas sejumlah hutang yang ditanggungnya.

Berdasarkan beberapa pendapat dari madzhab Hanafi dan madzhab Maliki serta ketentuan dalam Kompilasi Hukum Islam dan Undang-Undang Wakaf, ketika terjadi kepailitan terhadap harta warisan, maka harta warisan dapat ditetapkan sebagai boedel pailit untuk membayar hutang-hutang pewaris. Jika harta warisan tersebut habis maka wakaf wasiatnya menjadi batal, namun jika masih terdapat sisa, maka 1/3 dari sisa harta warisan tersebut dapat diambil untuk melaksanakan wakaf wasiat pewaris. Untuk wakaf wasiat yang belum ditunaikan, maka pembatalannya diperlakukan sama seperti wasiat, yaitu :34

1. Wasiat bisa dicabut dengan cara diucapkan secara lisan dan harus disaksikan oleh sekurang-kurangnya dua orang saksi, atau dapat berupa pernyataan tertulis dan juga tetap harus disaksikan sekurang-kurangnya dua orang saksi atau berdasarkan akta notaris.

2. Jika wasiat dilakukan dengan cara tertulis, maka untuk pecabutannya hanya dapat dilakukan secara tertulis juga yangdisaksikan oleh dua orang saksi atau berdasarkan akta Notaris.

3. Jika wasiat dibuat dengan Akta Notaris, maka hanya dapat dicabut berdasarkan Akta Notaris pula.

Namun apabila wakaf wasiat telah dilakukan dan telah didaftarkan, maka pembatalannya hanya dapat dilakukan dengan mengajukan permohonan pembatalan kepada Pengadilan Agama oleh para pihak yang merasa dirugikan karena adanya wakaf wasiat tersebut dengan menyebutkan alasan-alasan yang dibenarkan oleh hukum.

Pembahasan pada permasalahan ini menggunakan Teori Keadilan, karena terkait dengan substansi hukumnya yaitu mengenai akibat hukum wakaf wasiat ketika harta warisan pailit. Teori keadilan relevan untuk menjelaskan mengenai bagaimana keadilan dalam dimensi kepailitan, yaitu rasa keadilan bagi debitor dan kreditor serta para pihak yang berkepentingan. Teori keadilan melahirkan teori kemanfaatan dari Jeremy Betham, yaitu manusia akan bertindak untuk mendapatkan kebahagian yang sebesar-besarnya dan mengurangi penderitaan. Karena teori kemanfaatan merupakan rasionalisme dari keadilan, maka apibila keadilan telah tercapai otomatis akan

${ }^{34}$ Lihat Pasal 199 ayat (2), (3), dan (4) Kompilasai Hukum Islam 
memberikan manfaat bagi para pihak. Dalam hal ini diharapkan dapat memberikan kemanfaatan baik bagi kreditur maupun wakif yang telah berwasiat itu dalam hal pemberesan dan pengurusan harta warisan dalam kepailitan.

\section{Kesimpulan}

Hasil penelitian ini menyimpulkan bahwa: pertama, pelaksanaan wakaf wasiat dilakukan dengan tata cara perwakafan dan dilaksanakan oleh kuasa wakif atau orang yang menerima wasiat setelah pewasiat itu meninggal dunia, dalam hal ini penerima wasiat bertindak sebagai kuasa wakif. Ikrar wakaf baik secara lisan dan/atau tulisan dilakukan oleh kuasa wakif kepada Nadzir di hadapan Pejabat Pembuat Akta Ikrar Wakaf (PPAIW), serta dituangkan dalam Akta Ikrar Wakaf (AIW). Kedua, akibat hukum wakaf wasiat ketika harta warisan pewaris dinyatakan pailit, maka harta warisan dapat ditetapkan sebagai boedel pailit untuk membayar hutang-hutang pewaris. Jika harta warisan tersebut habis maka wakaf wasiatnya menjadi batal, namun jika masih terdapat sisa, maka $1 / 3$ dari sisa harta warisan tersebut dapat diambil untuk melaksanakan wakaf wasiat pewaris.

\section{Daftar Pustaka / Daftar Referensi}

\section{$\underline{\text { Buku }}$}

Al-Fauzan, S. (2006). Fiqih sehari-hari. Jakarta: Gema Insani.

Ali, M. C., Mashudi, H., \& Samsuddin, H. A. (1995). Kepailitan dan Penundaan Pembayaran. Bandung: Mandar Maju.

Asikin, Z. (2013). Hukum kepailitan dan penundaan kewajiban pembayaran utang di Indonesia. Bandung : Pustaka Reka Cipta

Bin Shalih al-Utsaimin, S. M. (2008). Panduan wakaf dan Wasiat menurut Al-Qur'an dan As-Sunnah.terj. Hudzaifah, A. Jakarta: Pustaka Imam Asy-Syafi'i.

Sastrawidjaja, M. S. (2006). Hukum Kepailitan dan Penundaan Kewajiban Pembayaran Utang. Bandung: Alumni.

Uwaidah, S. K. M., \& Kamil, S. (1998). Fiqih wanita. Jakarta: Pustaka Al-Kautsar.

\section{Jurnal}

Abdullah, J., \& Qodin, N. (2016). PENYELESAIAN SENGKETA WAKAF DALAM HUKUM POSITIF. ZISWAF: Jurnal Zakat dan Wakaf, 1(1), 1-18.

Al Arif, M. N. R., \& Rianto, N. (2010). Pemberdayaan masyarakat berbasis wakaf uang. Jurnal Asy-Syir'ah, Fakulti Syariah UIN Sunan Kalijaga Yogyakarta, 44(2), 813-828.

Hermawan, W. (2014). Politik hukum wakaf di Indonesia. Jurnal Pendidikan Agama Islam Ta'lim, 12(2). 
Hilmi, H. (2012). Dinamika pengelolaan wakaf uang: studi sosio-legal perilaku pengelolaan wakaf uang pasca pemberlakuan UU No. 41 tahun 2004 tentang wakaf. Ijtihad: Jurnal Wacana Hukum Islam dan Kemanusiaan, 12(2), 123-143.

Irawati, N. (2017). Wakaf Benda Bergerak Dalam UU No. 41 Tahun 2004 Dalam Tinjauan Fiqh Mazhab Syafii. Istidal: Jurnal Studi Hukum Islam, 4(2), 149-162

Kapero, H. V. (2018). AKIBAT KEPAILITAN TERHADAP HARTA PENINGGALAN DIKAITKAN DENGAN UNDANG-UNDANG NOMOR 37 TAHUN 2004 TENTANG KEPAILITAN DAN PENUNDAAN KEWAJIBAN PEMBAYARAN UTANG. LEX ET SOCIETATIS, 6(2).

Muhamad, N. H. N. (2017). WASIAT SEBAGAI INSTRUMEN PERANCANGAN HARTA ISLAM: PROSEDUR DAN PELAKSANAAN ((Bequest as an Instrument for Islamic Wealth Planning: Procedure and Application). Jurnal Hadhari: An International Journal, 9(1), 17-32

Nadriana, L. (2018). PERLINDUNGAN HUKUM TERHADAP HARTA AHLI WARIS DARI PEWARIS PENJAMIN AKTA PERSONAL GUARANTEE DI PERUSAHAAN PAILIT. Jurnal Bina Mulia Hukum, 2(1), 93-105.

Nuzha, N. (2015). Wasiat dan Hutang dalam Warisan. Jurnal Al-Qadau: Peradilan dan Hukum Keluarga Islam, 2(2).

Pradana, Y., Susilowati, E., \& Saptono, H. (2016). Kedudukan Ahli Waris Penanggung Perseorangan pada Perseroan Terbatas yang Dipailitkan secara Bersama-sama. Diponegoro Law Journal, 5(3), 1-19.

Samsidar, S. (2017). Urgensi Alat Bukti Akta Ikrar Wakaf Dalam Penyelesaian Sengketa Perwakafan. Jurnal SUPREMASI, 11(2).

Sulistiani, S. L. (2017). Analisis implementasi wakaf wasiat polis asuransi syariah di lembaga wakaf al-Azhar Jakarta. Ijtihad: Jurnal Wacana Hukum Islam dan Kemanusiaan, 17(2), 285-299.

Usman, N. (2016). Subjek-Subjek Wakaf: Kajian Fiqh Mengenai Wakif Dan Nazhir. Cakrawala: Jurnal Studi Islam, 11(2), 145-166.

\section{Disertasi :}

Husein, A. A. (2012). Pelaksanaan undang-undang wakaf Nomor 41 Tahun 2004 di Kecamatan Gebang Kabupaten Langkat (Doctoral dissertation, Pascasarjana UIN Sumatera Utara).

\section{$\underline{\text { Majalah }}$}

Isna Wahyudi, M., Alimuddin, Rahmat Arijaya. (2017). Hitam Putih Sengketa Wakaf. Majalah Peradilan Agama. Edisi XI April 2017

\section{Online/World Wide Web:}


Yusuf Zainal Abidin. (2018) Wasiat Oleh Debitur Pailit dalam http:/ / www.bhpjakarta.info/index.php?option=com_content\&view=article\&i $\underline{\mathrm{d}=317 \& \text { Itemid=159. }}$. (Diakses 12 Januari 2019). 